\title{
THE REVIEW OF POLITICS
}

Published Quarterly by the University of Notre Dame, Notre Dame, Indiana.

VoL. 2

JULY, 1940

No. 3

\section{Reflections On The War}

IT CANNOT be our task to determine the future or to advise what ought to be done. We have to be content with interpreting what has happened. After the start of the war, England and France were dominated by the belief that this struggle should be conducted in a defensive manner. Hitler had to be starved; a systematic and tight blockade would in the long run defeat him with comparatively small losses. This blockade would affect interior conditions in Germany, influence the mood of the German people. Perhaps it would drive the Leader to take offensive measures of despair, but these offensives would only accelerate the end. Captain Liddell Hart believed that modern defense, properly conducted, is superior to modern offense; indeed an attack could be made only with a large superiority of numbers and weapons, and, if successful, it would produce a dangerous exhaustion.

The English journals and reviews were full of discussions of what ought to be done with Germany after the war. One writer discussed projects of federation, and another opposed the development of a shortsighted mentality willing to repeat the blunders of Versailles. In France, there was the belief in the Maginot Line, which was admired by prominent visitors, in the military genius of General Gamelin, who was so anxious to save human lives, in the patriotism of Daladier. The warning example of Poland was not taken seriously. The Polish defeat was seen as the result of the ineptitude of the Polish military and civil leadership.

How are the military successes of Hitler to be explained? The decisive explanation rests in the abolition of the difference between war and peace-order by the Third Reich. Already in peacetime German economics were war-economics, directed not by the wishes of the con- 
sumers and the profit motive, but by the eventuality of war. Therefore, it was very easy to increase technical preparations, production of armaments, etc., after the open outbreak of war in September, 1939. Oppositely, England and France acted too slowly and cautiously. Because nothing happened in Western Europe after the war declarations, the British and French governments were afraid to impose too heavy burdens on the population. It will be of interest for future historians to investigate if the ratio of armaments between Germany and the Allies did not develop more and more in favor of the Hitler regime.

A second factor helped Nazi Germany: its ruling group was not bound by tradition. Therefore, it could likewise start from the beginning. The most modern techniques and the boldest organisation were possible. The experience of the 19th century was repeated in the 20th. Thorstein Veblen has explained in his study on Imperial Germany why the German industrial development could be accomplished with incomparable speed: Germany had not experienced an Industrial Revolution as England had, German economics were not handicapped by traditions, by existing investments; the ruling class had not yet changed into a leisure class. This technical superiority was used with the utmost energy and concentration of will. After the experiments in Poland and in Norway came the invasions of Belgium and The Netherland, then the crushing attack on France. These attacks were based on the following presumption: the existence of leadership with unlimited power and with henchmen, especially young ones, believing fanatically in this leadership and in the possibility of realizing the mission assigned to them. That the masses were not enthusiastic did not matter. Every possibility of expressing their discontent was destroyed by the totalitarian machinery of control. Therefore, they accepted the orders from above, perhaps with some grumbling as long as striking successes were not yet accomplished.

The hopes of the Allies that Hitler's pact with Stalin and Germany's attacks on neutrals would provoke an active resistance against Nazism in Europe were not fulfilled. Some states were simply not able to resistand doubtless the appeasement policy, culminating in the accords of Munich, had widely undermined confidence in England as well as in 
France. Fear, especially after the experience of Poland, was surely an important factor working for Nazi Germany. Middle-size and small states hoped against all hope that they would be somehow spared, and they believed, on the other hand, that intervention against Germany would be their ruin in any case.

The entrance of Italy in the war has definitely proved how decisive is today the logic of power. Mussolini waited until he knew on which side the overwhelming strength lay. But it would be wrong simply to identify power, as we observe it today, with brutal force. This power is not only connected with the most careful technical preparations and the use of mass propaganda, but also with the most refined exploitation of the weaknesses of the adversaries.

The strength of the strong is increased by the weakness of the weak. The strong uses the terminology of his adversary; he excites hope and expectation that agreements and understandings are possible, until the hour of open use of force has arrived. The pacifist mentality is used, which declares in advance that every resistance by force is meaningless, even immoral. Of course pacifism is favored and praised only in the other camp; at home maximum militarisation is accomplished. The strong exploits his adversary's mentality, which believes that a real war or a ruthless attack cannot happen in our time, for everybody allegedly knows that there can be no real victor in an armed conflict today. A mentality is skilfully exploited, which is dominated by old-fashioned political schemes and, therefore, does not realise that the real aims are today covered by opposite slogans. The Communists, for example, covered their aims in the so-called Popular Front by apparently democratic slogans, and other totalitarian movements disguised themselves as apparently traditionalistic-national ones. To undermine democracies, the fact of their being accustomed to democratic institutions is not neglected. The democracies regard it as simply impossible that they can be seriously threatened. That small minorities led by unknown adventurers will rise into power and obtain absolute control - how can such a thing happen? And helped by this false feeling of security and superiority the attack against the democracies can be carefully prepared and timed. Disintegration from within, caused by eternal discussions 
and clashes between different-interest groups facilitates the attack from without.

We observe today the combination of hypermodern techniques, military, and psychological techniques, with fantastic power-projects. The whole social order shall be organised in the simplest way - as a power-machine, run by small, daring, and ruthless minorities of leaders. The masses have to be educated in such a way that they will be ready to march and eventually to die, when the hour strikes. The masses will be confident in the leaders who successfully handle the modern techniques. Moral forces are not neglected but used for power-purposes.

As early as 1937 Pope Pius XI pointed out how holy names are misused for secular unholy purposes. That ruthless but, at the same time, utterly calculating power threatens today to obtain dominant position is the expression of the collapse of an epoch. To use the expression of T. S. Eliot, a neutral society without common belief in fundamental values seems to be only a transitory one. Its peace-will appears today as a simply negative one - as a result of fear and of tiredness. This neutrality is opposed by new "beliefs" and these beliefs use the skeptical, weak toleration of the neutral society to gain strength first of all, and then, as everybody realises now-to obtain absolute control.

But are these beliefs spiritually superior to those of the neutral society? The neutral society lived in the shadow of the Christian pastthe new beliefs will subjugate the Church, trying to make it at best into a kind of propaganda institution under the orders of those in political command. Self-sufficient political power is the aim as well as absolute domination here on earth. Immortality will rest in the earthly remembrance of the victorious warrior, not in Union with God. 